\title{
ANALISIS PENGARUH KUALITAS PRODUK, HARGA, DAN CITRA MEREK TERHADAP KEPUASAN DAN LOYALITAS KONSUMEN SAFINA FRIED CHICKEN
}

\author{
Didip Diandra \\ Tanri Abeng University \\ J1. Swadarma Raya No.58, Ulujami, Pesanggrahan, Jakarta, Indonesia \\ didip.diandra@tau.ac.id
}

\begin{abstract}
This research aims to analyze of the influence Product Quality, Price, and Brand Image to Customer Satisfaction and the effects to Customer Loyalty on Safina Fried Chicken at Cipinang Muara Jatinegara. Purposive sampling method has been selected to obtain data requires at this study. The research use 50 respondents and respondent's entire customer Safina Fried Chicken at Cipinang Muara. Path Coefficient analysis used as analytical method in this research. The result of this research shows that: Product Quality, Price, and Brand Image have significant influence on Customer Satisfaction and finally affect the Customer Loyalty simultaneously and partially. The only have dominant influenced to customer satisfaction among all variables was brand image.
\end{abstract}

Keyword: Product Quality, Price, and Brand Image, Customer Satisfaction, Customer Loyalty

\section{PENDAHULUAN}

Masyarakat sekarang sudah lebih cerdas dalam memilih produk yang akan mereka beli. Ditambah lagi dengan perkembangan teknologi yang menyebabkan banyaknya produk-produk baru yang bermunculan dipasaran. Namun, itu semua tidak akan mempengaruhi keputusan konsumen dalam memilik produk yang akan mereka beli. Banyak perusahaan baru bermunculan dengan inovasi produk yang menarik dan harga bersaing, tapi tidak sedikit juga yang merugi gara-gara mereka mengabaikan kualitas produk, harga, dan citra merek. Tentunya perusahaan menginginkan konsumen yang loyal terhadap mereka. 
Oleh karena itu, syarat bagi sebuah perusahaan untuk mencapai kesuksesan dalam berbisnis adalah menjaga kepuasan konsumen serta membuat mereka terus loyal dalam membeli produk kita. Karena semakin ketat persaingan bisnis dalam suatu industri tentu akan membuat konsumen semakin leluasa untuk berpindah pilihan pada produk yang lebih baik. Perusahaan yang mampu memberikan kepuasan kepada pelanggan akan mempunyai kekuatan untuk tetap eksis di pasar (Utari, 2010:137).

Salah satu faktor yang dapat mempengaruhi perilaku pembelian konsumen adalah kualitas produk. Kualitas produk adalah kemampuan suatu produk untuk melaksanakan fungsinya, meliputi daya tahan, keandalan, ketepatan, kemudahan operasi dan perbaikan, serta atribut bernilai lainnya (Kotler\&Armstrong, 2008:283).

Konsumen lebih memilih produk yang berkualitas, memiliki fitur yang bermutu, unik, dan inovatif. Bisnis yang bisa bertahan sepanjang waktu adalah bisnis yang memfokuskan perhatiannya pada kualitas produk. Kualitas produk berperan penting dalam membentuk kepuasan konsumen, selain itu juga erat kaitannya dalam menciptakan keuntungan bagi perusahaan. Semakin berkualitas produk yang diberikan oleh perusahaan maka kepuasan yang dirasakan oleh pelanggan akan semakin tinggi (Lasander, 2013:285).

Produk adalah segala sesuatu yang dapat ditawarkan ke pasar untuk memuaskan keinginan atau kebutuhan (Kotler, 2007:4). Menurut Tjiptono (2007:110-111) kualitas adalah upaya pemenuhan kebutuhan dan keinginan pelanggan serta ketepatan penyampaiannya untuk mengimbangi harapan pelanggan.

Kualitas berkaitan erat dengan kepuasan konsumen yang mengakibatan loyal. Kualitas menjadi cermin jelas bagi konsumen untuk menjalin hubungan yang saling menguntungkan dalam jangka panjang dengan perusahaan. Inilah yang diharapkan olah setiap perusahaan. Peningkatan daya pasar dan penyerapan kepuasan konsumen hanya bisa tercapai jika pemenuhan kualitas dilakukan dengan baik oleh pihak perusahaan, dalam istilah pemasaran disebut customer driven. Jadi, kualitas dan produk adalah suatu kesatuan yang tidak dapat 
dipisahkan. Produk yang ditawarkan ke pasar harus bisa memuaskan kebutuhan konsumen.

Hakikatnya konsumen dalam membeli produk harus memuaskan dan memenuhi keinginan mereka. Pengalaman kepuasan yang dirasakan berulang kali akan membuat dia menjadi loyal dan terus membeli suatu produk. Namun, tetap memperhatikan kualitas produk, harga, dan citra merek sebagai bahan pertimbangan.

Ayam goreng ala Kentucky atau versi bahasa inggrisnya Fried Chicken. Adalah fenomena baru dalam kehidupan masyarakat Indonesia saat ini dimana produk ini mulai menjamur dan menarik banyak pengusaha untuk memasuki industrinya karena memiliki karakter konsumen masing-masing. Sehingga peluang untuk memasuki pasar ini masih terbuka lebar. Disinilah Safina Fried Chicken bermain. Adalah perusahaan kecil penjual ayam goreng ala Kentucky yang berlokasi di Cipinang Muara, Jatinegara. Walaupun baru sekitar 2 (dua) tahun berdiri, Brand Safina Fried Chicken telah memiliki tujuh cabang yang tersebar di jabodetabek dan memiliki pelanggan tetap yang sangat loyal terhadap produk ayam goreng safina.

Lokasi resto yang sangat strategis yaitu di pertigaan Jalan sangatlah membantu pemasaran Safina Fried Chicken yang juga bersebelahan dengan Indomaret Cipinang Muara, dengan harga ayam goreng yang relatif murah yaitu Rp.7.000,- untuk semua potongan, seperti dada, dada atas, paha, paha bawah, dan sayap. Produk Safina Fried Chicken ini tergolong sangat murah dengan harga pukul rata.

Harga diatas tergolong sangat rendah bagi masyarakat Indonesia khususnya masyarakat Cipinang Muara, Jatinegara dibandingkan dengan usaha sejenis dan brand lokal yang sudah go-nasional. Hal ini yang menyebabkan Safina Fried Chicken terus berkembang, dan disukai banyak konsumen.

Harga menurut Roger (2006: 336) adalah uang atau pertimbangan lain (termasuk barang dan jasa lainnya) ditukar kepemilikan atau pengunaan barang atau jasa. Menurut Bearden (2001: 243), harga adalah jumlah uang yang dibayarkan oleh pembeli kepada penjual yang memperoleh produk atau jasa. 
Menurut Dhruv Gewal (2008: 271) "Merek adalah nama, istilah, desain, simbol, atau fitur lain yang mengidentifikasi satu penjual dari penjual yang lainnya." Bearden (2001:188) menjelaskan "Merek adalah nama, term, tanda, simbol, desain, atau kombinasi yang digunakan perusahaan untuk mengidentifikasi produk dan pembeda dari para pesaing." Citra perusahaan menjadi salah satu pegangan bagi konsumen dalam mengambil keputusan penting. Apalagi untuk makanan cepat saji seperti ayam goreng. Keputusan mereka untuk membeli ayam goreng sangat dipengaruhi oleh faktor kualitas produk dan harga terjangkau.

Pemasaran merupakan proses penyampaikan produk dari produsen kepada konsumen. Kotler \& Amstrong (2008:6) berpendapat bahwa "Pemasaran adalah proses dimana perusahaan menciptakan nilai bagi pelanggan dan membangun hubungan yang kuat dengan pelanggan dengan tujuan untuk menangkap nilai dari pelanggan sebagai imbalannya." Menurut Cannon et, al (2008:8), pemasaran adalah suatu aktivitas yang bertujuan mencapai sasaran perusahaan, dilakukan dengan cara mengantisipasi kebutuhan pelanggan atau klien serta mengarahkan aliran barang atau jasa yang memenuhi kebutuhan pelanggan atau klien dari produsen.

Pemasaran merupakan serangkaian prinsip untuk memilih pasar sasaran (target market), mengevaluasi kebutuhan konsumen, mengembangkan barang dan jasa, pemuas keinginan, memberikan nilai kepada konsumen dan laba bagi perusahaan.

Dalam bauran pemasaran yang paling banyak digunakan saat ini yaitu produk, harga, tempat, dan promosi (Kotler \& Amstrong, 2008 : 62).

a. Produk yang berkualitas memberikan kesan tersendiri bagi masyarakat, produk yang ditawarkan harus mengena pasar sasaran. Dalam hal ini produsen Safina Fried Chicken menawarkan berbagai macam produknya dengan tawaran yang sama.

b. Harga adalah jumlah uang yang harus dibayarkan konsuen untuk memperoleh suatu barang. Maka produsen Safina Fried Chicken telah memperhitungkan besarnya harga yang dikenakan untuk setiap produk yang dipasarkan yaitu Rp.7.000,- pukul rata untuk setiap jenis produk yang ditawarkan. Hal ini 
merupakan suatu keberanian yang dilakukan oleh pihak produsen tentu dengan strategi yang tepat serta perhitungan yang tepat.

c. Faktor lokasi atau tempat dimana resto itu berdiri merupakan tempat yang sangat strategis untuk menemukan konsumen yang loyal. Safina Fried Chicken melakukan ekspansi pasar dengan sistem buka cabang, sehingga merek mereka semakin dikenal oleh banyak orang.

d. Promosi adalah suatu kegiatan yang menyampaikan manfaat produk diutamakan kepada konsumen baru, namun tidak mengabaikan konsumen tetap. Dalam hal ini Safina Fried Chicken melakukan promosi menggunakan media sosial serta memanfaatkan aplikasi modern jasa pemesanan makanan seperti Go-Jek, dan Grab-Food sehingga produk mereka dikenal dan dibeli oleh masyarakat Jakarta.

\section{a) Kepuasan Konsumen}

Menurut Kotler (1996:188) kepuasan konsumen ada pada pembelian namun tergantung pada kinerja produk itu sendiri yang harus sesuai dengan harapan pembeli. Seorang pelanggan mungkin mengalami berbagai tingkat kepuasan. Bila kinerja produk tidak sesuai dengan harapan, maka pelanggan akan merasa tidak puas. Bila kinerja melampaui harapan, pelanggan amat puas atau bergairah untuk membeli kembali.

Kepuasan konsumen terhadap suatu produk memastikan bahwa perusahaan telah berhasil menciptakan produk yang disukai masyarakat. Kepuasan konsumen adalah keadaan emosional, reaksi pasca pembelian mereka dapat berupa kegembiraan, kejengkelan, kesenangan, kemarahan bahkan ketidakpuasan Lovelock (2005:102). Hal ini yang mendasari obsesi perusahaan untuk terus berinovasi dan meningkatkan kualitas produknya karena kepuasan konsumen selalu berhubungan dengan loyalitas konsumen, pangsa pasar, dan keuntungan.

Puas atau tidak puas konsumen dalam mengkonsumsi suatu produk akan berpengaruh langsung pada perasaannya, apalagi jika sudah kecewa dipastikan konsumen akan menghentikan pembelian kembali (Suwarman, 2011: 387). 
Menurut Lupiyoadi dalam Amanah (2010:9), ada lima faktor yang harus diperhatikan oleh perusahaan dalam menentukan tingkat kepuasan konsumen, yaitu:

a. Kualitas produk

Kepuasan konsumen akan tercapai jika produk yang dibeli dan digunakan ternyata berkualitas dan sesuai dengan harapan konsumen.

b. Kualitas pelayanan

Kualitas pelayanan harus super cepat dan berkualitas. Dalam artian bahwa konsumen merasa puas setelah mendapatkan pelayanan yang diharapkan.

c. Emosional

Konsumen adalah manusia yang memiliki perasaan, rasa dan sensitifitas. Jika dia merasa bangga dan percaya dengan produk kita, maka itu akan memberikan keuntungan langsung kepada perusahaan.

d. Harga

Harga harus sesuai dengan kualitas. Namun untuk mendapatkan produk yang berkualitas tidak perlu mahal. Harga memang tidak pernah berbohong. Tapi konsumen selalu bisa menghargai produk berkualitas yang mereka harapkan.

e. Biaya

Kepuasan konsumen juga akan tercapai jika dia tidak mengeluarkan biaya tambahan dan membuang waktu hanya untuk mendapatkan suatu produk yang berkualitas. Kemudahan mendapatkan suatu produk bisa menjadi bahan pertimbangan dalam membeli produk.

\section{b) Loyalitas Konsumen}

Dalam istilah bisnis, loyal artinya adalah keputusan konsumen untuk membeli produk secara berulang-ulang. Griffin dalam Kotler \&Keller (2007:175) mendifinisikan loyalitas sebagai komitmen yang dipegang kuat untuk membeli lagi atau berlanggan lagi produk atau jasa tertentu di masa depan meskipun ada 
pengaruh situasi dan usaha pemasaran yang berpotensi menyebabkan peralihan prilaku.

Menurut Kotler \& Keller (2010) loyalitas adalah komitmen mendalam untuk melakukan pembelian ulang terhadap produk atau jasa tertentu meskipun terdapat pengaruh situasional dan usaha-usaha pemasaran yang berpotensi menimbulkan perilaku berpindah.

Seorang konsumen akan dengan mudah berpindah kepada produk lain apabila dia tidak mendapatkan keinginannya pada produk yang sebelumnya. Konsumen yang loyal memang memberikan banyak manfaat dan keuntungan kepada konsumen Lovelock dan Wirtz (2007) salah satunya konsumen yang loyal akan menyampaikan berita positif kepada orang lain mengenai perusahaan (word of mouth) dan bersedia untuk membayar lebih tinggi (premium price).

Maka Jhonston (2010:76) berpendapat dalam hubungan jual beli, proporsi nilai perusahaan harus cukup kuat untuk memindahkan konsumen dari kepuasan ke komitmen pada produk perusahaan untuk mencapai tingkat loyalitas konsumen. Maka secara otomatis konsumen yang loyal tadi akan mempunyai banyak alasan mengapa mereka tidak beralih dari produk anda ke produk yang lain.

Terdapat beberapa indikator yang bisa digunakan untuk mengukur loyalitas konsumen Tjiptono (2011:85) diantaranya adalah:

1. Pembelian ulang

2. Kebiasaan mengkonsumsi merek tersebut

3. Selalu menyukai merek tersebut

4. Tetap memilih merek tersebut

5. Yakin merek tersebut yang terbaik

6. Merekomendasikan merek tersebut kepada orang lain

Tidak dapat diabaikan lagi bahwa jelas loyalitas konsumen merupakan tujuan akhir dari setiap perusahaan. Tapi mereka banyak yang tidak menyadari dan selalu mencari konsumen yang potensial. Padahal komitmen konsumen untuk melakukan pembelian ulang yang menentukan puas atau tidak nya seorang konsumen. Lalu ketika seorang konsumen dengan bangga dan percaya diri 
menggunakan produk Anda, maka dipastikan bahwa dia merasa puas dengan kualitas produk, harga, dan brand yang Anda miliki.

Sadar akan pentingnya loyalitas konsumen dalam menjaga keberlangsungan hidup perusahaan, maka perusahaan hendaklah membangun relati atau hubungan yang baik dengan konsumen tidak hanya memikirkan profit atau keuntungan semata, namun lebih daripada itu yaitu kebutuhan dan keinginan konsumen perusahaan.

Berdasarkan teori-teori dan pembahasan diatas, maka peneliti menggambarkan model penelitian sebagai berikut:

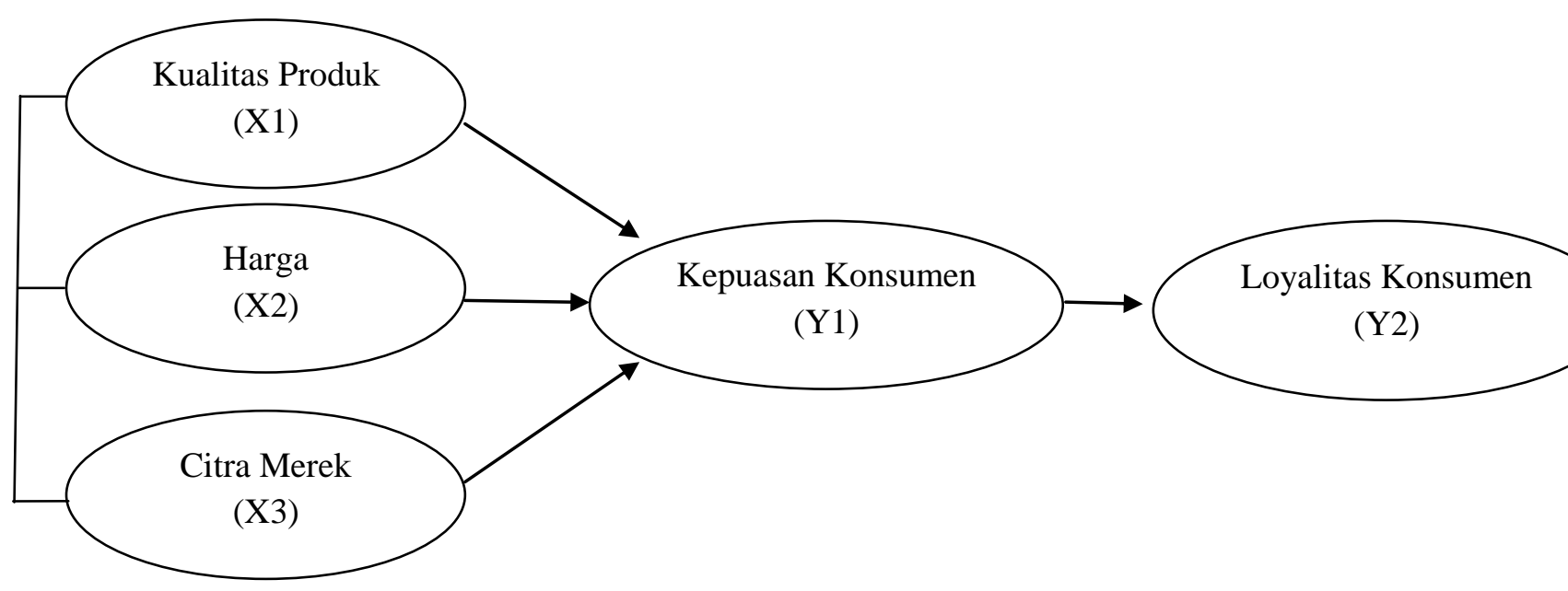

Gambar 1.

Model Penelitian

\section{METODOLOGI PENELITIAN}

Objek pada penelitian ini adalah Safina Fried Chicken, sebuah resto cepat saji dengan produk ayam goreng ala Kentucky yang beralamat di Jl. Cipinang Muara 1, Simpang Indomaret, Jatinegara, Jakarta Timur. Penelitian ini dilakukan pada awal tahun 2017, dalam kurun waktu 3 bulan.

Populasi dalam penelitian ini adalah generalisasi yang terdiri atas objek dan subjek dari jumlah tertentu yang ditetapkan oleh peneliti untuk belajar dan menarik kesimpulan (Sugiyono, 2008:57). Dalam penelitian ini populasinya 
adalah konsumen yang melakukan pembelian ayam goreng Safina Fried Chicken di Cipinang Muara dan sekitarnya.

Sampel adalah anggota dari populasi yang dipilih dengan menggunakan prosedur tertentu yang diharapkan dapat mewakili populasi (Sugiyono,2008:57). Sampel dalam penelitian ini adalah penduduk dan warga di wilayah cipinang muara dan sekitarnya yang membeli dan mengkonsumsi produk ayam goreng Safina Fried Chicken. Peneliti menggunakan metode Purposive sampling yang sesuai dengan penilaian peneliti karena peneliti percaya bahwa sample yang dipilih berdasarkan kenyamanan atau penilian peneliti (Malhotra, 1999).

Penelitian ini menggunakan 50 kuesioner responden dengan Skala Likert dengan tujuan untuk menandai tingkat kesepakatan atau tidak kesepakatan terhadap masing-masing pernyataan tentang objek stimulasi (Ghozali,2006:41). Penelitian ini juga menggunakan dua jenis data, yakti data primer dan data sekunder. Data primer yang digunakan adalah data mengenai masalah khusus yang dihadapi oleh pertanyaan penelitian. Data diperoleh melalui penyebaran kuesioner kepada sampel. Sedangkan data sekunder diperoleh melalui studi literature terhadap buku, jurnal, dan sumber lain yang relevan dengan topik penelitian.

Pertanyaan yang diajukan kepada responden adalah pertanyaan tertutup (close ended questions). Selanjutnya jawaban responden akan dioleh dengan menggunakan software SEM PLS 3.

Metode analisis data yang digunakan dalam penelitian ini adalah uji validitas dan reliabilitas. Hal ini dilakukan untuk menjamin bahwa alat ukur yang digunakan benar-benar dapat mengukur objek yang diukur (valid) dan menunjukkan hasil yang konsisten (reliable). Reliabilitas menunjukkan konsistensi dan sejauh mana pengukuran itu dilakukan. Menurut imam Ghazali (2006:46) pengukuran reliabilitas dapat dilakukan dengan dua cara yaitu Pengukuran ulang dimana seseorang diberikan pertanyaan yang sama pada waktu yang berbeda dan Pengukuran satu kali dengan membandingkan hasilnya dengan pertanyaan lain atau korelasi antara pertanyaan dan jawaban. Maka daripada itu penelitian ini menggunakan Cronbach Alpha diatas 0,6 (Malhotra, 1999). 
Analisis Jalur (Path Coefficient) merupakan analisis pola-pola hubungan antara variabel dengan tujuan untuk mengetahui secara langsung atau secara tidak langsung pengaruh variabel independen (eksogen) terhadap variabel dependen (endogen) (Ridwan dan Engkos,2007:2).

Analisis ini digunakan untuk mengetahui sejauh mana pengaruh Kualitas Produk (X1), Harga (X2), Citra Merek (X3) ke Kepuasan Pelanggan (Y1) dan dampaknya ke Loyalitas Konsumen (Y2), baik secara langsung maupun tidak langsung. Maka definisi operasional yang digunakan dalam menjawab perumusan masalah mengenai pengaruh kualitas produk, harga, dan citra merek terhadap kepuasan konsumen dan loyalitas konsumen menggunakan instrument pengukuran dan indikator-indikator sehingga dimensi Kualitas Produk (X1) memiliki 3 indikator yaitu Daya Tahan (X1), Fitur (X2), dan Kesesuaian dengan spesifikasi (X3), Harga (X2) memiliki 2 indikator yaitu Harga sesuai dengan kualitas produk (H1), dan harga terjangkau (H2), Citra Merek (X3) memiliki 2 indikator yaitu Kekuatan (strengness)(C1), dan Keunikan (uniqueness)(C2), Kepuasan Konsumen (Y1) dengan 3 indikator yaitu Kualitas (K1), emosional (K2), dan harga (K3), dan Loyalitas Konsumen (Y2) dengan 3 indikator yaitu Pembelian ulang (L1), yakin terhadap merek (L2), dan merekomendasikan merek kepada orang lain (L3).

Koefisien determinasi (R2) pada dasarnya mengukur seberapa jauh kemampuan model untuk menjelaskan variasi dalam variabel dependen. Uji statistic F pada dasarnya menunjukan apakah semua variabel independen atau variabel bebas yang dimasukan kedalam model telah bersama sama berpengaruh terhadap variabel dependen Ghazali (2006:203). Uji statistik T yang bertujuan untuk menentukan seberapa besar pengaruh masing- masing variabel independen (X) individual secara parsial terhadap variabel terikat (Y) (Ghozali, 2006:88).

\section{ANALISIS DAN PEMBAHASAN}

Peneliti menganalisa pengaruh kualitas produk, harga, dan citra merek terhadap kepuasan dan loyalitas konsumen Safina Fried Chicken. Jumlah kuesioner yang disebarkan adalah sebanyak 50 eksemplar kuesioner, dengan jumlah pengembalian sebanyak 50 eksemplar, jadi response rate pada penelitian 
ini adalah sebesar $100 \%$. Kuesioner tersebut dibagi menjadi lima faktor utama, yaitu penggunaan kualitas produk (X1) dengan 3 pertanyaan, harga (X2) dengan 2 pertanyaan, citra merek (X3) dengan 2 pertanyaan, Kepuasan konsumen (Y1) dengan 3 pertanyaan, dan loyalitas konsumen (Y2) dengan 3 pertanyaan. Jadi, jumlah pertanyaan dalam kuesioner sebanyak 13 butir pertanyaan dengan jumlah responden sebanyak 50 responden. Dengan demikian, semua kuesioner dapat diolah untuk menjadi penelitian.

\section{a. Model Pengukuran (Outer Model)}

Pada penelitian ini akan dilakukan pengujian validitas dan reliabilitas pada masing-masing variabel laten yaitu variabel kualitas produk, harga, dan citra merek terhadap kepuasan dan loyalitas konsumen dengan menggunakan bantuan software SEM PLS 3. Ukuran refleksif individual dikatakan valid jika memiliki nilai loading factor dengan variabel laten yang ingin diukur $\geq 0.5$, jika salah satu indikator memiliki nilai loading factor $<0.5$ maka indikator tersebut harus dibuang (didrop) karena akan mengindikasikan bahwa indikator tidak cukup baik untuk mengukur variabel laten secara tepat. Berikut adalah hasil output diagram jalur persamaan struktural pada PLS dengan menggunakan software SmartPLS 3.

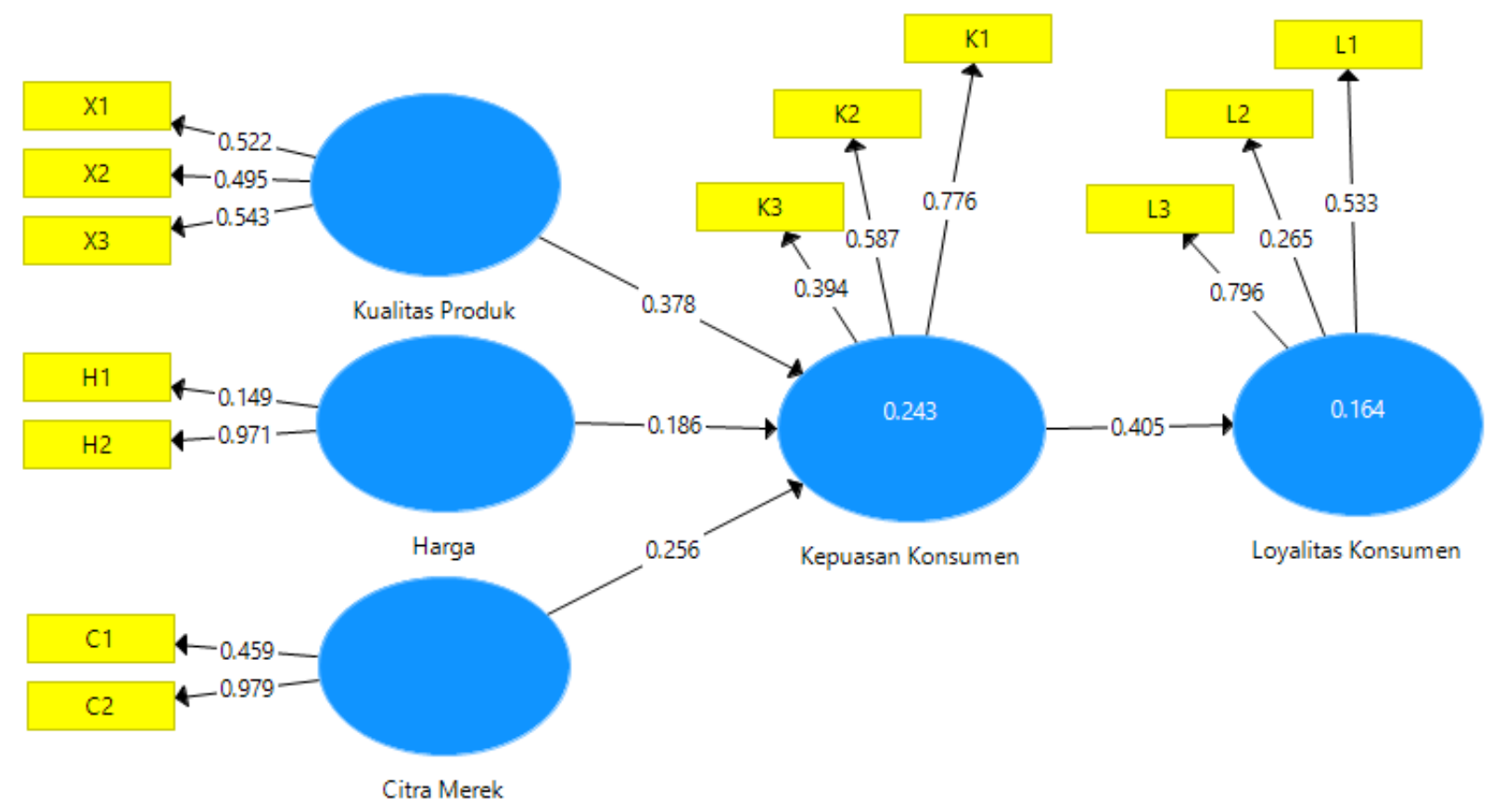

Gambar 1. Diagram jalur persamaan struktual PLS dengan software SmartPLS 3 
Suatu indikator dinyatakan valid jika mempunyai loading factor di atas 0,5 terhadap konstruk yang dituju. Dari gambar diatas terlihat bahwa terdapat 6 (enam) variabel indikator dengan nilai loading $(\lambda)<0.5$ yaitu pada variabel indikator $\mathrm{X} 1, \mathrm{X} 2, \mathrm{H} 1, \mathrm{C} 1, \mathrm{~K} 3$, dan $\mathrm{L} 2$, maka indikator tersebut harus dibuang (didrop). Berikut adalah hasil output ke dua, diagram jalur persamaan struktural pada PLS dengan menggunakan software SmartPLS 3.

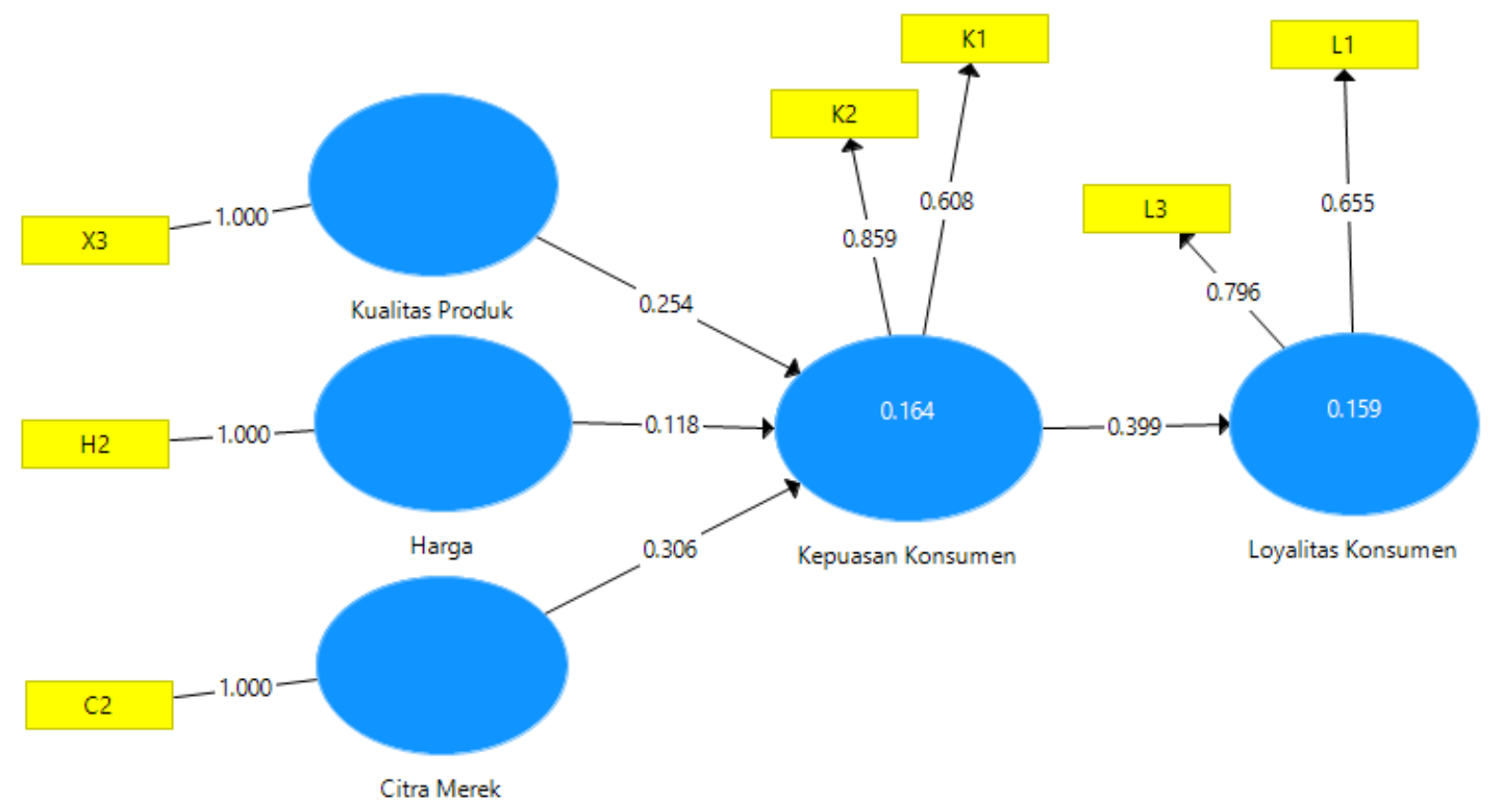

Gambar 2. Diagram jalur persamaan struktual PLS dengan software SmartPLS 3

Dari gambar diatas dapat disimpulkan bahwa :

\section{Untuk uji validitas :}

Tabel 1. Uji validitas

\begin{tabular}{|c|c|c|c|c|c|c|}
\hline Variable & $\begin{array}{c}\text { Origina } \\
1 \\
\text { Sample } \\
\text { (O) }\end{array}$ & $\begin{array}{l}\text { Sampl } \\
\text { e } \\
\text { Mean } \\
(\mathrm{M})\end{array}$ & $\begin{array}{c}\text { Standard } \\
\text { Deviatio } \\
n \\
\text { (STDEV } \\
\text { ) }\end{array}$ & $\begin{array}{c}\mathrm{T} \\
\text { Statistic } \\
\mathrm{s} \\
(\mid \mathrm{O} / \mathrm{STD} \\
\mathrm{EV} \mid)\end{array}$ & $\begin{array}{c}\mathrm{P} \\
\text { Value } \\
\mathrm{S}\end{array}$ & Keterangan \\
\hline X3 <- Kualitas Produk_ & 1.000 & 1.000 & 0.000 & & & $\begin{array}{l}\text { Valid dan } \\
\text { signifikan }\end{array}$ \\
\hline $\mathrm{H} 2<-$ Harga & 1.000 & 1.000 & 0.000 & & & Valid dan \\
\hline
\end{tabular}




\begin{tabular}{|c|c|c|c|c|c|c|}
\hline C2 <- Citra Merek & 1.000 & 1.000 & 0.000 & & & $\begin{array}{l}\text { signifikan } \\
\text { Valid dan } \\
\text { signifikan }\end{array}$ \\
\hline $\begin{array}{l}\text { K1 <- Kepuasan } \\
\text { Konsumen_ }\end{array}$ & 0.608 & 0.582 & 0.329 & 1.850 & 0.065 & Valid \\
\hline $\begin{array}{l}\text { K2 <- Kepuasan } \\
\text { Konsumen_ }\end{array}$ & 0.859 & 0.756 & 0.307 & 2.799 & 0.005 & Valid \\
\hline L1 <- Loyalitas Konsumen & 0.655 & 0.610 & 0.315 & 2.081 & 0.038 & Valid \\
\hline L3 <- Loyalitas Konsumen & 0.796 & 0.712 & 0.350 & 2.274 & 0.023 & Valid \\
\hline
\end{tabular}

Berdasarkan tabel diatas dapat disimpulkan bahwa nilai loading dari hubungan variabel indikator X3 dengan konstruk Kualitas Produk, hubungan variabel indikator $\mathrm{H} 2$ dengan konstruk Harga, hubungan variabel indikator C2 dengan konstruk Citra Merek, hubungan variabel indikator K1 dan K2 dengan konstruk Kepuasan Konsumen, hubungan variabel indikator L1 dan L3 dengan konstruk Loyalitas Konsumen. Masing-masing memiliki nilai loading $(\lambda) \geq 0.5$, dan memiliki nilai T-statistik > 1.64 pada taraf signifikansi $\alpha=0,1$.

Dengan demikian variabel indikator kesesuaian dengan spesifikasi yaitu produk yang ditawarkan sesuai dengan standar yang sudah ditentukan dikatakan valid untuk mengukur konstruk kualitas produk, dan variabel indikator harga terjangkau yaitu harga yang ditawarkan terjangkau oleh konsumen dapat dikatakan valid untuk mengukur konstruk harga, variabel indikator keunikan (uniqueness) yaitu produk bervariasi dari segi penampilan fisik dan diferensiasi dari produk dengan merek lain dapat dikatakan valid untuk mengukur konstruk citra merek. Kemudian variabel indikator kualitas produk dan emosional yaitu konsumen membeli produk sesuai dengan harapan dan merasa bangga dengan produk yang dibeli dikatakan valid untuk mengukur konstruk laten Kepuasan Konsumen, variabel indikator pembelian ulang dan merekomendasikan merek kepada orang lain dapat dikatakan valid untuk mengukur konstruk laten Loyalitas Konsumen.

Model yang dapat ditulis adalah sebagai berikut :

$\mathrm{X} 3=1.000$ Kualitas produk +0.000

$\mathrm{H} 2=1.000$ Harga +0.000

$\mathrm{C} 2=1.000$ Citra Merek +0.000 
$\mathrm{K} 1=0.608$ Kepuasan Konsumen +0.329

$\mathrm{K} 2=0.859$ Kepuasan Konsumen +0.307

L1 $=0.655$ Loyalitas Konsumen +0.315

L3 $=0.796$ Loyalitas Konsumen +0.350

\section{Untuk Uji Reliabilitas :}

Dalam penelitian ini suatu variabel dikatakan cukup reliabilitas bila variabel tersebut mempunyai nilai construc reliality lebih besar dari 0,6. Berikut adalah hasil pengujian reabilitas pada masing-masing variabel laten dengan bantuan software SmartPLS 3.

Tabel 2. Pengujian Reliabilitas

\begin{tabular}{llll}
\multicolumn{1}{c}{ Variable } & AVE & $\begin{array}{c}\text { Reliabilitias } \\
\text { Komposit } \\
\rho_{c}\end{array}$ & Keterangan \\
\hline Kepuasan & 0.554 & 0.707 & Reliabel \\
Konsumen_ & 0.531 & 0.692 & Reliabel \\
Loyalitas Konsumen & 0.000 & 1.000 & Reliabel \\
Kualitas Produk_ & 1.000 & 1.000 & Reliabel \\
Harga & 1.000 & 1.000 & Reliabel \\
Citra Merek & 1.000 & & \\
Sumber : Data olahan SmartPLS & &
\end{tabular}

Berdasarkan hasil tabel diatas, dapat disimpulkan bahwa untuk variabel laten eksogen Kualitas produk, Harga, dan Citra merek memiliki nilai AVE > 0.5 dan $\rho_{c} \geq 0.6$ begitu juga dengan variabel laten endogen Kepuasan Konsumen dan Loyalitas Konsumen memiliki nilai AVE $>0.5$ dan $\rho_{c} \geq 0.6$ maka dapat disimpulkan bahwa indikator-indikator yang digunakan yaitu pada variabel (X3, H2, C2, K1, K2, L1, dan L3) mempunyai reabilitas yang cukup baik atau mampu untuk mengukur konstruknya.

\section{b. Model Struktural (Inner Model)}

Model struktural dapat dievaluasi dengan melihat nilai $\mathrm{R}^{2}$ pada variabel endogen dan koefisien parameter jalur (path coeficient parameter). Berikut hipotesis yang diangkat dalam penelitian ini adalah:

H1 : Kualitas Produk berpengaruh terhadap Kepuasan dan Loyalitas Konsumen 
H2 : Harga berpengaruh terhadap Kepuasan dan Loyalitas Konsumen

H3 : Citra Merek berpengaruh terhadap Kepuasan dan Loyalitas Konsumen

Hasil dari model struktural dapat ditunjukkan pada tabel berikut:

Tabel 3. Model Struktural

\begin{tabular}{cccccc} 
& Original & & & $\mathrm{T}$ & \\
Sample & Sample & Standard & Statistics & $\mathrm{P}$ \\
& $(\mathrm{O})$ & Mean & Deviation & $(\mid \mathrm{O} / \mathrm{STDE}$ & Values \\
& (Koefisien & $(\mathrm{M})$ & $($ STDEV $)$ & $\mathrm{V} \mid)$ & \\
\hline Parameter) & & & & \\
\hline
\end{tabular}

Kualitas Produk_ -> Kepuasan

Konsumen

$0.254 \quad 0.256$

0.156

1.620

0.106

Harga -> Kepuasan Konsumen_

0.118

0.105

0.163

0.727

0.468

Citra Merek -> Kepuasan

Konsumen_

0.306

0.308

0.146

2.089

0.037

Kepuasan Konsumen_->

Loyalitas Konsumen

$\begin{array}{ll}0.399 & 0.419\end{array}$

0.175

2.280

0.023

Sumber : Data olahan SmartPLS

Pengaruh hubungan variabel laten eksogen terhadap variabel laten endogen (Kepuasan Konsumen), lalu variabel laten endogen (kepuasan konsumen dan Loyalitas konsumen) pada tabel diatas dapat dijelaskan sebagai berikut:

1. Koefisien parameter jalur yang diperoleh dari hubungan antara variabel kualitas produk dengan Kepuasan Konsumen sebesar 0.254 dengan nilai Tstatistik $1.620<1,96$ pada taraf signifikansi $\alpha=0,05$ (5\%) yang menyatakan bahwa tidak terdapat pengaruh yang signifikan antara kualitas produk dengan Kepuasan Konsumen. Nilai positif pada koefisien parameter artinya adalah semakin baik kualitas produk maka pengukur kepuasan konsumen yaitu pada loyalitas konsumen akan bertambah.

2. Koefisien parameter jalur yang diperoleh dari hubungan antara variabel harga dengan Kepuasan Konsumen sebesar 0.118 dengan nilai T-statistik $0.727<$ 1,96 pada taraf signifikansi $\alpha=0,05$ (5\%) yang menyatakan bahwa tidak terdapat pengaruh yang signifikan antara harga dengan Kepuasan Konsumen. Nilai positif pada koefisien parameter artinya adalah semakin murah harga maka pengukur kepuasan konsumen yaitu pada loyalitas konsumen akan bertambah. 
3. Koefisien parameter jalur yang diperoleh dari hubungan antara variabel citra merek dengan Kepuasan Konsumen sebesar 0.306 dengan nilai T-statistik $2.089>1,96$ pada taraf signifikansi $\alpha=0,05(5 \%)$ yang menyatakan bahwa terdapat pengaruh yang signifikan antara citra merek dengan Kepuasan Konsumen. Nilai positif pada koefisien parameter artinya adalah semakin terkenal citra merek maka pengukur kepuasan konsumen yaitu pada loyalitas konsumen akan bertambah.

4. Koefisien parameter jalur yang diperoleh dari hubungan antara variabel Kepuasan Konsumen dengan Loyalitas Konsumen sebesar 0.399 dengan nilai T-statistik $2.280>1,96$ pada taraf signifikansi $\alpha=0,05$ (5\%) yang menyatakan bahwa terdapat pengaruh yang signifikan antara Kepuasan Konsumen dengan Loyalitas Konsumen. Nilai positif pada koefisien parameter artinya adalah semakin tinggi kepuasan konsumen maka loyalitas konsumen akan bertambah.

Tabel 4. Nilai R-Square $\left(\mathrm{R}^{2}\right)$

\begin{tabular}{llllll}
\multicolumn{1}{c}{ Variabel } & $\begin{array}{l}\text { Original } \\
\text { Sample } \\
(\mathrm{O})\end{array}$ & $\begin{array}{l}\text { Sample } \\
\text { Mean } \\
(\mathrm{M})\end{array}$ & $\begin{array}{l}\text { Standard } \\
\text { Deviation } \\
(\text { STDEV })\end{array}$ & $\begin{array}{l}\text { T Statistics } \\
(|\mathrm{O} / \mathrm{STDEV}|)\end{array}$ & $\begin{array}{l}\mathrm{P} \\
\text { Values }\end{array}$ \\
\hline Kepuasan Konsumen_ & 0.164 & 0.232 & 0.093 & 1.765 & 0.078 \\
Loyalitas Konsumen & 0.159 & 0.206 & 0.115 & 1.386 & 0.166 \\
Sumber : Data olahan SmartPLS & & & &
\end{tabular}

Dari hasil model persamaan diatas diperoleh nilai $\mathrm{R}^{2}$ untuk variabel Kepuasan Konsumen sebesar 0.164 yang artinya nilai tersebut mengindikasikan bahwa variasi kepuasan konsumen dapat dijelaskan oleh variabel konstruk (kualitas produk, harga, dan citra merek) hanya sebesar $16.4 \%$ sedangkan sisanya yaitu sebesar $84.6 \%$ dipengaruhi oleh variabel lain yang tidak terdapat dalam model penelitian.

Dari hasil model persamaan diatas diperoleh nilai $\mathrm{R}^{2}$ untuk variabel Loyalitas Konsumen sebesar 0.159 yang artinya nilai tersebut mengindikasikan bahwa variasi loyalitas konsumen dapat dijelaskan oleh variabel konstruk kepuasan konsumen hanya sebesar $15.9 \%$ sedangkan sisanya yaitu sebesar $85.1 \%$ dipengaruhi oleh variabel lain yang tidak terdapat dalam model penelitian. 
Seperti yang diketahui bahwa faktor-faktor yang mempengaruhi kepuasan konsumen tidak hanya variabel konstruk kualitas produk, harga, dan citra merek saja. Akan tetapi terdapat faktor lain yaitu seperti daya tahan produk, estetika, persaingan harga, kekuatan produk, dan kemudahan mendapatkan produk. Dengan demikian dapat disimpulkan bahwa variabel konstruk kualitas produk, harga, dan citra merek hanya mampu menjelaskan $16.4 \%$ sebagai faktor terhadap kepuasan konsumen, sedangkan $84.6 \%$ nya dijelaskan oleh variabel daya tahan produk, estetika, persaingan harga, kekuatan produk, dan kemudahan mendapatkan produk. Begitu juga dengan variabel konstruk kepuasan konsumen yang hanya mampu menjelaskan $15.9 \%$ sebagai faktor terhadap loyalitas konsumen, sedangkan $85.1 \%$ nya dijelaskan oleh variable lainnya seperti kemudahan mendapatkan produk, yakin terhadap merek, dan selalu menjadi pilihan pertama.

\section{SIMPULAN}

Berdasarkan analisis data dan pembahasan hasil penelitian maka dapat ditarik kesimpulan sebagai berikut :

1. Berdasarkan metode pengukuran diagram jalur persamaan struktual PLS dengan software SmartPLS 3 dapat disimpulkan bahwa untuk variabel laten eksogen Kualitas Produk, Harga, dan Citra Merek memiliki nilai AVE > 0.5 dan $\rho_{c} \geq 0.6$ begitu juga dengan variabel laten endogen Kepuasan Konsumen dan Loyalitas Konsumen memiliki nilai AVE $>0.5$ dan $\rho_{c} \geq 0.6$ maka dapat disimpulkan bahwa indikator-indikator yang digunakan yaitu pada variabel (X3, H2, C2, K1, K2, L1, dan L3) mempunyai reabilitas yang cukup baik atau mampu untuk mengukur konstruknya. Itu artinya bahwa Kualitas produk, Harga, dan Citra Merek dapat mempengaruhi Kepuasan Konsumen dan Loyalitas Konsumen.

2. Berdasarkan metode struktural dengan dengan melihat nilai $\mathrm{R}^{2}$ pada variabel endogen dan koefisien parameter jalur (path coeficient parameter), maka hasil dari model struktural menunjukkan bahwa variasi kepuasan konsumen dapat dijelaskan oleh variabel konstruk (kualitas produk, harga, dan citra merek) yang menyebabkan loyalitas konsumen semakin bertambah secara signifikan. 


\section{DAFTAR PUSTAKA}

Ananta, Aris, "The Indonesian Economy: Entering a New Era", Institute of Southeast Asian Studies, Singapore, 2011.

Cooper, Donald R. "Business Research Methods". McGraw Hill. New York, 2006.

Chin, W. "The Partial Least Square Approach for Structural Equation Modeling”. Cleveland. Ohio, 1998

Ghozali dan Fuad. "Structural Equation Modeling; Teori, Konsep, dan Aplikasi dengan Program Lisrel 8.54”, Badan Penerbit Universitas Diponegoro, Semarang. 2005.

Hair et al,. "Multivariate Data Analysis, Sixth Edition”. New Jersey : Prentice Hall, Upper Saddle River. 2006.

Kotler, Philip.”Marketing Management” Pearson Education Ltd, London. 2009.

, \& Amstrong, Gery. "Prinsip-prinsip Pemasaran”. Edisi kedua belas, Jilid Pertama, Erlangga, Jakarta, 2008. and Kevin L. Keller. "Marketing Management". $14^{\text {th }}$ Edition. Prentice Hall: New Jersey. 2012.

Muhidin, Sambas Ali, dan Mamam Abdurahman, "Analisis Korelasi, Regresi, dan Jalur dalam Penelitian”. Pustaka Setia, 2007.

Nurmayanti Hidayat. Bambang Widjanarko Otok. "Pemodelan Structural Equation Modeling (SEM) Berbasis Varians Pada Derajat Kesehatan Di Propinsi Jawa Timur 2010", Seminar Nasional Penelitian, Pendidikan dan Penerapan MIPA, Fakultas MIPA, Universitas Negeri Yogyakarta, 2 Juni 2012.

Rangkuti, Freddy, “Measuring Customer Satisfaction”. PT. Gramedia Pustaka Utama Jakarta. 2003.

Ronald J. Ebert and Ricky W. Griffin, Pearson, "Business Essentials”, Ninth Edition. 2008.

Sugiyono. "Metode Penelitian Bisnis (Pendekatan Kualitatif, Kuantitatif dan $R \& D)$ ". Cetakan kedua belas. Alphabet, Jakarta, 2008.

Tambunan, Tulus Dr. "Perekonomian Indonesia”, Penerbit Ghalia Indonesia, Bogor, 2009.

Thomas, R. Chistopher, Charles Maurice. Managerial Economic : "Foundations of Business Analysis and Strategy”, Twelfth Edition, McGraw Hill Education. 2013.

Tjiptono, Fandy, Ph.D. “Manajemen \& Strategi Merek”. Andi Offset, Yogyakarta, 2011. 